\title{
Tożsamość - religia - miasto. Konteksty obecności tożsamości religijnej w lokalnej przestrzeni życia publicznego w Europie Środkowo-Wschodniej ${ }^{1}$
}

Streszczenie: Tożsamość religijna w społeczeństwach Europy Środkowo-Wschodniej ulega aktualnie silnym przemianom związanym zarówno z konsekwencjami transformacji systemowej, zmianami kulturowymi, jak i przemianami wewnątrz Kościołów. W nowych demokratycznych warunkach w państwach takich jak Polska, Słowacja i Ukraina tożsamość religijna staje się także jedną z tożsamości zbiorowych manifestowanych w sferze publicznej i istotnych nie tylko w kontekście dyskursu publicznego, ale także w kontekstach lokalnych, tj. tożsamości lokalnej i tożsamości miejsca.

Autorka przedstawia w artykule refleksje dotyczące znaczeń religijnej tożsamości zbiorowej w lokalnej przestrzeni publicznej. Są to spostrzeżenia wyłaniające się z prowadzonych badań jakościowych. Zarysowują się tutaj trzy istotne konteksty znaczeń tożsamości religijnej w lokalnej przestrzeni życia publicznego: 1) specyfika roli religijności i religii w życiu publicznym w tej części Europy, 2) kulturowe i instytucjonalne znaczenia identyfikacji religijnej w odniesieniu do tożsamości lokalnej i tożsamości miejsca, 3) problematyka narracji wokół wieloreligijnego dziedzictwa sakralnego w społecznościach lokalnych, która wprowadza nowy sposób percepcji religijnej tożsamości jako kulturowego zasobu związanego z miejscem i pamięcią.

Słowa kluczowe: tożsamość religijna, Europa Środkowo-Wschodnia, sfera publiczna, społeczność lokalna, dziedzictwo

W Europie Środkowej i Wschodniej sprawy religii i tożsamości lokalnych wydają się aktualnie szczególnie istotne. Wielka zmiana społeczna, jaka na-

1 Artykuł powstał w ramach projektu badawczego pt.: Miejsce religii w sferze publicznej. Tożsamości religijne w wieloreligijnych regionach Europy Środkowo-Wschodniej na przyktadzie wybranych regionów Polski, Ukrainy i Stowacji. Projekt realizowany z funduszy Narodowego Centrum Nauki, konkurs OPUS VI, nr rejestracyjny 2013/09/B/HS6/03076, umowa nr UMO-2013/09/B/HS6/03076. 
stąpiła w ciągu niespełna dwóch dekad, z jednej strony zainicjowała szeroki trend religijnego odrodzenia i powrotu do tradycji religijnych i kulturowych (także w wymiarze lokalnym), a z drugiej otworzyła przed społeczeństwami regionu drogę szybkich przemian społeczno-kulturowych związanych z oddziaływaniem globalnych trendów, tj. uniwersalizujący kosmopolityzm i odkrycie wartości lokalizmu czy partykularyzmu odrębności². Społeczność lokalna i miasto stały się nową areną życia publicznego, a kwestie religijnej identyfikacji wyłoniły się w nich jako obszar istotnych interakcji społecznych. Jednocześnie identyfikacje religijne w omawianych społeczeństwach podlegają licznym redefinicjom związanym zarówno z wpływem globalnym trendów, tj. indywidualizacji czy sekularyzacji, zmian stylu życia, jak i różnicującej się perspektywy wobec roli religii i Kościołów jako instytucji społecznych. Aktualnie w przestrzeni publicznej stykają się zatem tradycyjny, ludowy czy kościelny wzór religijnej identyfikacji z dynamiką przemian religijności i tożsamości religijnej. Jednocześnie nakładające się w tej części Europy identyfikacje narodowe i religijne spotykają się z odradzającą się lub odkrywaną na nowo różnorodnością religijną i jej historią, zróżnicowaną dla poszczególnych miast i krajów.

W wielu miastach Europy Środkowej i Wschodniej fakt ten przynosi także kolejne znaczenia religijnej identyfikacji w lokalnej sferze publicznej - zabytki sakralne oraz niematerialne dziedzictwo są bowiem zasobem kulturowym, który może mieć znaczenie dla budowania wizerunku czy walorów turystycznych okolicy. Splot tych uwarunkowań wskazuje, iż tożsamość religijna z pewnością jest jedną z istotnych tożsamości zbiorowych. Jej znaczenia w życiu publicznym są jednak wielopoziomowe i skomplikowane, podobnie jak religijne tożsamości mieszkańców regionu. Interesująca wydaje się zatem refleksja na temat kontekstów obecności tożsamości religijnej w lokalnej przestrzeni życia publicznego. Niniejszy artykuł ma charakter zbioru spostrzeżeń dotyczących omawianej problematyki, które wyłaniają się na marginesie prowadzonych badań jakościowych. W artykule koncentruję się na trzech wskazanych we wstępie kwestiach, które określają i kształtują znaczenia tożsamości religijnej w lokalnym życiu publicznym. Do najważniejszych z nich należą: 1) specyfika tożsamości religijnej w społeczeństwach przechodzących transformacje, 2) manifestacje tożsamości w lokalnej przestrzeni życia publicznego, w szczególności małego miasta, 3) zarysowujące

2 R. Robertson: Mapping the Global Condition: Globalization as the Central Concept. "Theory, Culture and Society" 1990, No. 7 (2-3), s. 15-30. 
się aktualnie w tym regionie pytania o materialne dziedzictwo sakralne i pamięć różnorodności religijnej.

W artykule posługuję się pojęciem przestrzeni życia publicznego i definiuję je za Margaret Sommers jako „przestrzeń, w której obywatele wyrażają swoje opinie, identyfikacje i angażują się w negocjacje i kontestacje życia politycznego i społecznego"3. Jak podkreśla Edmund Wnuk-Lipiński, tak zarysowana sfera publiczna obejmuje sferę dyskursu publicznego, działania instytucji publicznych oraz zwyczajowych praktyk życia zbiorowego. W tym sensie jest także przestrzenią uzgodnień aksjologicznych i dotyczących społecznego ładu, w której identyfikacje religijne są jedną z wielu zbiorowych tożsamości ${ }^{4}$.

\section{Tożsamość religijna w życiu publicznym - od przekonań do przynależności}

Złożoność pojęcia tożsamości ujawnia się ze szczególną siłą w odniesieniu do tożsamości religijnej. Stanowi ona jedną z pierwszych opisanych w socjologii identyfikacji społecznych o zbiorowym charakterze i znaczeniu kulturowym, wytwarzającą wzory postępowania i przynależności ${ }^{5}$. Współcześnie zbiorowe tożsamości manifestowane w sferze publicznej są jednocześnie wynikiem indywidualnych przekonań, jak i społecznie podzielanych wartości czy motywacji, podstawą poczucia przynależności i zaangażowania społecznego, a często także punktem odniesienia lub legitymizacją aktywności grup społecznych w życiu publicznym ${ }^{6}$. Odpowiedź na pytanie - kim jestem? wyraża bowiem zbiór wyobrażeń, sądów i przekonań, które stanowić moga podstawy aktywności różnych uczestników życia publicznego.

Zgodnie z tradycją socjologiczną (interakcjonizmu symbolicznego) tożsamość społeczna ma charakter procesualny i negocjacyjny. Jest zbiorem wyobrażeń, sądów i przekonań o samym sobie lub wyodrębnionej zbiorowości

3 M. R. Sommers: Citizenship and the place of the public sphere: Law, community, and the political culture in the transition to democracy. "American Sociological Review" 1993, No. 58 (5), pp. 587-620.

4 E. Wnuk-Lipiński: Socjologia życia publicznego. Warszawa 2006, „Scholar”, S. 104

5 J. Szacki: Historia myśli socjologicznej. Warszawa 2004, PWN, s. 383-390.

6 Por. M. Castells: Sita tożsamości. Warszawa 2008, PWN; Z. Mach: Symbols, Conflict and Identity. Essays in Political Anthropology. Albany, NY 1993, Suny Press. 
$(\mathrm{My})^{7}$. Istotą funkcjonowania tożsamości jest działanie aktora społecznego, poprzez które dokonywane są wybory i w konsekwencji manifestowana jest podmiotowość ${ }^{8}$. Centrum tożsamości jest jednak znaczenie przypisywane owym działaniom. Jak podkreśla Charles Taylor: „To, czym jestem jako podmiot, moja tożsamość, jest określane zasadniczo przez sposób, w jaki rzeczy mają dla mnie znaczenie" ${ }^{\prime}$. Religia kształtuje owe znaczenia. Badacze społeczni podkreślają jednak, iż społeczne i kulturowe znaczenie „wyłania się z procesu interakcyjnej interpretacji dokonywanej przez uczestników dialogu. Nie może ono być subiektywne, gdyż jest wynikiem dialogu, nie jest też obiektywne, gdyż nie istnieje niezależnie od uczestników i poza łączącym ich stosunkiem wzajemnych oddziaływań"10. Tożsamości nie sposób zatem definitywnie określić stałą definicją lub regulacją instytucjonalnie ani jedynie subiektywnym doświadczeniem. Często stosowanym objaśnieniem tego fenomenu jest wskazanie na trzy komponenty współczesnych tożsamości ${ }^{11}$ : emocjonalny (odczucia, motywacje wewnętrzne), kognitywny (wyuczone treści, wiedza, informacje) oraz behawioralny (praktyki i działania manifestujące i potwierdzające daną przynależność, często o charakterze obyczajowym lub tradycyjnym). Halina Mielicka, analizując współczesną tożsamość religijną w Polsce na podstawie powyższego schematu, podkreśla rozłączność tożsamości religijnej indywidualnej i społecznej. Ta pierwsza stanowi bowiem wynik refleksji i odczuć oraz umiejscowienia w świecie pojęć i wartości przekazanych w procesie socjalizacji, ta druga odnosi się do ról i przynależności, społecznych struktur działania. Tożsamość oparta na wartościach religijnych może być zatem rozumiana na wiele sposobów. Jak zauważa Robert Szwed, stanowi ona „mechanizm adaptacji, czynnik integracji z grupą, kreuje sferę komunikacji, jest także mechanizmem selekcji, który wskazuje, jakie elemen-

7 A. Kojder (red.): Encyklopedia socjologii. Warszawa 2002, Oficyna Naukowa, S. 252.

8 P. Sztompka: Socjologia. Analiza społeczeństwa. Kraków 2006, Wydawnictwo "Znak", s. 138-155.

9 Ch. Taylor: Sources of the Self: Making of Modern Identity, 1989, za: A. Elliot: Koncepcje "Ja”. Warszawa 2008, Wydawnictwo Sic!, s. 13.

10 G. Woroniecka: Interakcja symboliczna a hermeneutyczna kategoria przed-rozumienia. Warszawa 2003, Oficyna Naukowa, s. 11.

11 H. Mielicka: Tożsamość indywidualna a tożsamość społeczna jako wymiar religijności. W: M. Libiszowska-Żółtkowska (red.): Tożsamości religijne w społeczeństwie polskim. Socjologiczne studium przypadków. Warszawa 2009, „Difin”, s. 20. 
ty przyjąć, jakie odrzucić [...]"12. W sferze publicznej manifestuje się zatem od poziomu osobistej identyfikacji z prawdami wiary w sensie teologicznym i Kościołem w sensie instytucjonalnym, po syntezę religii i kultury aktualizowaną w konkretnym środowisku społecznym. Identyfikacja religijna posiada w tym sensie „kulturowy kostium”, często wbudowana jest w tożsamość lokalną, narodową lub kulturowo-cywilizacyjną. Religia zaliczana jest także do wartości rdzennych, czyli takich, które budują wspólnotę na bazie wspólnych idei, norm postępowania, autorytetów i sposobu widzenia świata. Tego typu tożsamość religijna może być silnie związana z etnicznością lub wspólnotą lokalną i bywa interpretowana z jednej strony - jako zasób symboliczny odpowiedzialny za wzmacnianie poczucie My, a z drugiej - podkreśla się podobieństwo więzi społecznych występujących we wspólnotach religijnych i etnicznych lub narodowych ${ }^{13}$. Często bowiem granice lokalności czy „swojskości" pokrywają się z przynależnością religijną.

Podsumowując, określenie identyfikacji religijnej w kategoriach przynależności religijnej lub wyznaniowej (deklarowanej lub wynikającej z danych kościelnych) stanowi jedynie dane bazowe, które w lokalnej przestrzeni społecznej i geograficznej są określane i interpretowane poprzez różne formy komunikacji społecznej, procesy sakralizacji i desakralizacji przestrzeni publicznej realizują się w życiu codziennym zbiorowości - od kultywowania zwyczajów po umiejscowienie symboli. Tożsamość religijna manifestuje się w kontekście innych zbiorowych przynależności. Uwaga ta jest szczególnie aktualna w regionie Europy Środkowej i Wschodniej.

\section{Specyfika tożsamości religijnej społeczeństw Europy Środkowej i Wschodniej}

Do najczęściej wymienianych przejawów obecności religii w życiu publicznym społeczeństw Europy Środkowej i Wschodniej zaliczyć można rytualizm religijny, przywiązanie do obyczajów i tradycji religijnych oraz znaczenie Kościołów jako instytucji i aktorów życia publicznego ${ }^{14}$. Zdaniem Wojciecha

12 R. Szwed: Tożsamość religijna. W: M. Libiszowska-Żółtkowska, J. Mariański (red.): Leksykon socjologii religii. Zjawiska - badania - teorie. Warszawa 2004, Wyd. Księży Werbistów „Verbinum”, s. 428.

13 Zob. G. Babiński: Religia a konflikty etniczne. Kategorie pojęciowe. Analizy wzajemnych relacji. Kraków 1994, „Nomos”, s. 157-166.

14 D. Pollack, O. Muller: Religiousness in Central and Eastern Europe: Towards 
Świątkiewicza w społeczeństwach tych religia wyraża się na wiele sposobów. „Gdy analizujemy przejawy obecności religii w życiu społecznym, chodzi już o coś więcej, niż tylko o instytucjonalnie zorganizowane formy życia społeczno-religijnego, ale o aksjologiczne podstawy ładu społecznego, pojmowanie człowieka i wartości jego życia, sposoby myślenia, podstawowe pojęcia moralne, kryteria oceniania, zasoby wiedzy podręcznej, w jakie wyposaża religia i Kościół swoich wiernych, a także tych wszystkich, którzy pozostają w kręgu ich oddziaływania"15. Tak szerokie oddziaływanie religii jest przez niektórych badaczy określane mianem religii kulturowej, tj. takiej, która „rezyduje w kulturze", a jej znaczenia niekoniecznie związane są z indywidualnymi przekonaniami, lecz stanowią ogólny horyzont wartości, których należy przestrzegaćc ${ }^{16}$, lub też są pojmowane jako element tożsamości narodowej.

W społeczeństwach postkomunistycznych tożsamości religijne ulegają jednak silnym przemianom. Następują modyfikacje zarówno sposobów identyfikacji religijnej, postaw wobec religii, jak i redefinicje funkcjonowania instytucji religijnych. Zaobserwować można silny kulturowy wymiar tożsamości religijnej - procesy indywidualizacji i pluralizacji religijnej widoczne są m.in. w oddzieleniu się indywidualnych przekonań od przynależności do instytucji religijnych, a także w tęsknocie za religią jako odpowiedzią na wyzwania współczesności. Sprawy religii i religijnej tożsamości są tutaj także częstym przedmiotem dyskusji publicznej. Po pierwsze identyfikacja religijna jest silnie związana ze statusem instytucji religijnych, które pełniły role względnie niezależnej przestrzeni dyskusji publicznej w poprzednim systemie, a w historii tych obszarów mają także zasługi dla edukacji i kultury oraz

Individualisation? W: I. Borowik (red.): Religions, Churches and Religiosity in post-Comunist Europe. Kraków 2006, „Nomos”, s. 22-37; I. Borowik: Religijne oblicze Polski na tle Europy. W: A. Wójtowicz: Kultury religijne. Perspektywy socjologiczne. Tyczyn 2005, WSSG, s. 31-43.

15 W. Świątkiewicz: Relikt przeszłości czy żywa codzienność? Refleksje wokót badań socjologicznych nad religijnościa wspótczesna w krajach wyszehradzkich. W: J. Budniak, A. Kasperek (red.): Polska - Czechy - Stowacja. Oblicza religijności. Katowice 2011, PAU - Oddział Katowice, s. 29-30.

16 W ten sposób opisywane jest np. znaczenie katolicyzmu w Polsce czy Irlandii lub prawosławia w Rosji. Zob.: N. J. Demerath: The Rise of "Cultural Religion" in European Christianity: Learning from Poland, Northern Ireland and Sweden. „Social Compass" 2000, No. 47, s. 127-139; I. Borowik: Religious Landscape on Central and Eastern Europe after Communism. W: J. A. Beckford, N. J. Demerath III, The Sage Handbook of the Sociology of Religion. London 2007, Sage Publications, s. 654-669. 
wsparcia procesów narodotwórczych. Przesłanie demokratycznych przemian przez część elit społecznych jest więc łączone także ze swego rodzaju duchową przemianą i rozumiane w kategoriach moralności czy „powrotu do prawdy". Identyfikacja religijna jest także istotna w dyskursach nacjonalistycznych i patriotycznych na krajowych scenach politycznych. Jednocześnie istotna jest dbałość o gwarancję wolności religijnych, a znacząca liczba ludności prezentuje identyfikacje religijne o charakterze hybrydycznym, łączące różne praktyki religijne, lub traktuje je jako selektywnie wybierany element szeroko pojętej kultury, co ujawnia się w takich określeniach jak „wierzący niepraktykujący” czy „niewierzący prawosławni”.

Po 1989 roku zamrożone dotychczas identyfikacje religijne stanowią istotny głos w wielu debatach publicznych w kwestiach światopoglądowych i dotyczących określania ładu społecznego. Identyfikacja religijna obywatela, osoby publicznej czy funkcjonariusza publicznego może mieć znaczenie zarówno jako element obywatelskiej cnoty, tradycji kulturowej, jak i prywatnego przekonania. Przemiany transformacyjne pobudziły także zainteresowanie kwestiami pluralizmu kulturowego i religijnego. Z jednej strony obserwuje się religijne odrodzenie i szerokie uczestnictwo w niektórych formach religijności, np. pielgrzymki, z drugiej pojawia się ciekawość religijnych Innych, a w dyskursie publicznym zaczynają ujawniać się także trudne problemy historii relacji międzyreligijnych i międzyetnicznych w społeczeństwach regio$n u^{17}$. Relacje te oraz narracje o nich obecne na arenie publicznej nabieraja znaczeń w kontekstach poszczególnych społeczności lokalnych dla określania przynależności, swojskości i obcości w demokratycznym społeczeństwie. Dla społeczeństw regionu wyjątkowo aktualne jest więc stwierdzenie, iż „zrozumienie przestrzeni i społeczeństwa wymaga wzięcia pod uwagę praktyk religijnych, bowiem zarówno organizacyjny, instytucjonalny wymiar tych praktyk, jak i indywidualne doświadczenie znajdują odzwierciedlenie w organizacji przestrzennej i społecznej"18.

17 W Polsce można wskazać w tym kontekście na kwestie relacji polsko-żydowskich i antysemityzmu, na Słowacji na problemy dotyczące mniejszości etnicznych, na Ukrainie problematykę relacji tożsamości narodowej i religijnej po 1989 roku.

18 C. Brace, A. R. Bailey, D. C. Harvey: Religion, Place and Space: A Framework for Investigating Historical Geographies of Religious Identities and Communieties. „Progress in Human Geography” 2006, No. 30, s. 29. http://phg.sagepub.com/conn tent/30/1/28 (10.10.2014). 


\section{Zróżnicowanie manifestacji tożsamości religijnej w lokalnej przestrzeni życia publicznego}

Na podstawie trwających badań można stwierdzić, iż tożsamość religijna w lokalnej przestrzeni publicznej manifestuje się głównie w trzech obszarach - religijnych tradycji i zwyczajach kulturowych, aktywności i działalności Kościołów i grup religijnych oraz okazjonalnie innych instytucjonalnych i zbiorowych uczestników życia publicznego, a także w narracji dotyczącej pamięci i historii, która obejmuje relacje międzyreligijne oraz stosunek do religijnego dziedzictwa obecnego na danym terenie. Dwie pierwsze manifestacje są zwykle związane z parafią oraz różnego rodzaju działalnością stowarzyszeniową. Wydaje się także, iż liczne zbiorowe praktyki religijne o charakterze publicznym, tj. pielgrzymki, procesje, wydarzenia kulturalne, są nierozdzielnie związane $\mathrm{z}$ kulturową tożsamością małego miasta i interpretowane przez samych mieszkańców w kontekście lokalnego poczucia wspólnoty czy tradycji ${ }^{19}$. W tym miejscu istotne wydaje się spojrzenie na lokalną przestrzeń publiczną i schematyczną ocenę religijności mieszkańców miast i wsi. Ośrodkiem lokalnej sfery publicznej w Europie Środkowo-Wschodniej są bowiem głównie niewielkie miasta. Schematyczna ocena lokalnej zbiorowości wydaje się jednak silnie ograniczać interpretacje znaczenia tożsamości religijnej w lokalnej sferze publicznej.

Małe miasto jako obszar społeczny znajduje się w podwójnej opozycji, między typem idealnym miasta-metropolii i ideą kultury miejskiej, a także typem idealnym wsi i schematycznym obrazem społeczności wiejskiej. Małe miasto zachowuje elementy społeczności lokalnej typu wiejskiego z silną rolą sąsiedztwa, bezpośredniością interakcji, kontrolą społeczną, lokalnym ekocentryzmem i podziałem na Swoich i Obcych. Jednocześnie posiada elementy charakteru miejskiego związane z większym zróżnicowaniem społeczno-zawodowym, dostępnością instytucji, autonomią i prywatnością jednostki, niższą kontrolą społeczną. Jak przypomina Misztal, socjologiczna ocena miasta jest równie biegunowa. Miasto jest bowiem zarówno zagrożeniem dla społecznych reguł i wartości, w tym tożsamości religijnej, jak i miejscem twórczym, oferującym przestrzeń i tolerancję dla nowych przekonań i stylów

19 G. Odoj: Tożsamość kulturowa społeczności małomiasteczkowej. Katowice 2007, UŚ, s. 213, 221. 
życia ${ }^{20}$. Znaczenia tożsamości religijnej w małym mieście regionu są jakby laboratorium różnorodności - można odnaleźć tutaj przykłady definiowania religijnej tożsamości w sposób typowy dla społeczności tradycyjnych, gdzie religia jest dana, jednoznaczna i wymaga posłuszeństwa jednostek wobec jej autorytetu. Cechy te współgrają np. z opisami tzw. religijności ludowej lub kościelnej ${ }^{21}$. Tożsamość religijna w tym samym ośrodku może jednak być także identyfikacją o cechach zupełnie odmiennych, np. indywidualnie wybieraną, podlegającą refleksji i krytyce, czy też ograniczoną do przestrzegania religijnych obyczajów. Jak podkreśla Leszek Gajos, w przeszłości religia miała istotne znaczenie i silnie oddziaływała na wszystkie sfery życia społeczności lokalnych. Współcześnie pojawiają się nowe obszary życia społecznego, które pozostają poza wpływem wartości wynikających z religii ${ }^{22}$. W przestrzeni małych miast stykają się więc tradycyjny, ludowy i kościelny wzór religijnej identyfikacji z dynamiką przemian społecznych.

Niezmiennie znaczące w lokalnej przestrzeni publicznej pozostają role instytucji religijnych, które pełnią liczne funkcje publiczne. Parafie „koncentrują energie lokalnej społeczności”, pełnią funkcję jednego z organizatorów życia publicznego, w wielu miejscach są ośrodkiem życia kulturalnego i edukacyjnego. Współcześnie role parafii w życiu lokalnych społeczności są jednak także zróżnicowane i silnie związane z rodzajem społecznych więzi, w ramach których religijna identyfikacja jest urzeczywistniana. Podejście humanistyczne postrzega społeczność lokalną jako zbiorowość o charakterze wspólnoty symbolicznej, zamieszkującej przestrzeń, która ma dla niej wartość ze względu na określone formy kulturowe, ich znaczenie i sens ${ }^{23}$. Zarysowana wyżej specyfika tożsamości religijnej w społeczeństwach postkomunistycznych (socjalizacja religijna, rytualizm religijny, siła ludowej religijności) może być także interpretowana jako czynniki wzmacniające religijne identyfikacje oraz więzi $\mathrm{z}$ nimi związane. Zgodnie z typologią więzi społecznych tożsamość religijna

20 W. Misztal: Maria Ossowska: miasto i moralność. W: W. Misztal, J. Styka (red.): Stare i nowe struktury społeczne w Polsce. Czynniki miastotwórcze w okresach wielkich zmian społecznych. T. III. Lublin 2002, UMCS, s. 87-99.

21 Zob. E. Ciupak: Katolicyzm ludowy w Polsce: studia socjologiczne. Warszawa 1973, „Wiedza Powszechna”, s. 30-35.

${ }^{22}$ L. Gajos: Wartości religijne a tożsamość mieszkańców wsi Podkarpacie w drodze do Unii Europejskiej. W: I. Borowik, K. Leszczyńska (red.): Wokót tożsamości. Teorie, wymiary, ekspresje. Kraków 2008, „Nomos”, s. 297.

23 P. Sztompka, Socjologia. Analiza społeczeństwa. Kraków 2006, „Znak”, s. 140. 
w społeczności lokalnej związana jest w pierwszej kolejności z więzami małego i średniego zasięgu, takimi jak parafia, sąsiedztwo czy lokalne grupy o charakterze stowarzyszenia. To w ramach tych grup organizuje się bowiem życie religijne społeczności lokalnej. Ze względu na rodzaj więzi łączących uczestników podobne manifestacje tożsamości religijnej, takie jak procesja lub obchody świąt religijnych, mogą być także interpretowane w różny sposób. Np. $\mathrm{w}$ anonimowym społeczeństwie wielkomiejskim są to wydarzenia o charakterze ludycznym, gdzie Kościół występuje w roli organizatora ${ }^{24}$, z kolei w małym miasteczku podkreśla się ich wagę integrującą, połączenie identyfikacji miejsca z wymiarem wiary i kultu religijnego ${ }^{25}$. Warto przypomnieć za Pawłem Rybickim, iż „więź społeczna tworzy się i utrzymuje poprzez to, co ludzi łączy i przez to, co ludzi dzieli w zbiorowym współżyciu: nie albo przez jedno, albo przez drugie [...]"26. Więź wykształca się zatem nie tylko ze względu na homogeniczność - jednolitość i podobieństwo, lecz także przez komplementarność - odniesienie do siebie różnic. Wydaje się, że uwzględnienie tych obserwacji jest niezbędne, by ukazać różnorodność tożsamości religijnej obecnej aktualnie w lokalnej przestrzeni publicznej. Obserwacja ta kieruje również uwagę na kolejny kontekst narracji wokół tożsamości religijnej - pamięć i historię różnorodności religijnej na danym obszarze.

\section{Historia, religijne dziedzictwo i jego nowe znaczenia}

W geograficznej przestrzeni małych miast Europy Środkowej i Wschodniej często charakterystyczną architekturą centrum miasta są budowle sakralne. Ośrodki te w wielu wypadkach nie podlegały XIX-wiecznym przekształceniom urbanistycznym i zachowane zostały w nich dawne wzory z centralnym położeniem katedr i budynków sakralnych. Dla wielu małych miast owa przestrzeń sakralna związana jest także z historycznym początkiem osadnictwa. Duży wpływ miały tu przemiany struktury kościelnej, a także zmienność po-

24 B. Kopczyńska-Jaworska: Różnorodność obyczajów miejskich, W: D. Bieńkowska (red.): Wielkie miasto. Czynniki integrujące i dezintegrujące. Łódź 1995, UŁ, s. 76-85.

25 H. Mielicka: Odpusty w matym miasteczku. W: M. Meducka, R. Renz (red.): Miasteczka polskie w XIX i XX wieku jako zjawisko kulturowo-obyczajowe. Kielce 1998, WSP, s. 167-186.

26 M. Halamska: Więź społeczna we współczesnym społeczeństwie polskim. Rekonstrukcja wedtug typologii Pawła Rybickiego, za: P. Rybicki, Społeczeństwo miejskie. Warszawa 1976, PWN, s. 691. 
lityki władz wobec religijnej różnorodności na przestrzeni wieków. Historycy wskazują także, iż w małych miastach całej Europy Wschodniej specyficzny stosunek do funkcji handlowych miasta łączył się z pojmowaniem zbiorowej tożsamości przez mieszkańców. Jak wskazuje Jerzy Jedlicki, historycznie kultura i mentalność Europy Wschodniej przeciwstawiała się idei postępu cywilizacyjnego i mieszczańskiej etyce konkurencji ${ }^{27}$. „Ostrzegając przed nią i opierając się jej, odnajduje w sobie i we własnej tradycji wartości rodzime, mogące służyć za fundament innej cywilizacyjnej budowy. Nie będzie ona wprawdzie świeciła złotem, lecz przykładem ducha, zaś jej zasadą nie będzie współzawodnictwo, [...] lecz [...] wspólnota"28. Tego rodzaju metafizyczny obraz miasta łączy w historii tego regionu narracje religijnej aksjologii z niechęcią do cudzoziemszczyzny jako swoistą łączność aksjologii z geografią i znaczeniem przestrzeni. Historycy zwracają jednak uwagę, iż pomimo religijnego horyzontu życia publicznego w dawnych miastach nie występowała jednak jedność religijna, ani też konformizm religijny w życiu publicznym. Miasta były także przestrzenią religijnych konfliktów.

Chętnie dziś przywoływanym faktem jest różnorodność kulturowa i religijna w XIX-wiecznych miasteczkach Europy Środkowej. Historycznie był to obszar wielokulturowy w tym sensie, iż współistniały tutaj grupy chrześcijan różnych wyznań (katolików, protestantów, prawosławnych) oraz Żydów. Warto jednak pamiętać, iż owo współistnienie religii nie wpisuje się we współczesne definicje wielokulturowej społeczności ${ }^{29}$. Granice dzielące poszczególne grupy przebiegały od ich statusu prawnego na danym terytorium po społeczne rozgraniczanie Naszych od Obcych w życiu codziennym miasta. Świadectwa historyczne wielu miast pokazują, że grupy religijne działały tutaj na zasadzie współistnienia, tj. obok siebie, jako zamknięte społeczności. Granice między nimi przebiegały nie tylko na płaszczyźnie religijnej, ale także często ze względu na pochodzenie narodowe i etniczne, a także ze względu na status prawny czy przynależność klasową. Współpraca w sferze publicznej

27 J. Jedlicki: Jakiej cywilizacji Polacy potrzebują. Studia z dziejów idei $i$ wyobraźni XIX wieku. Warszawa 2002, Wyd. W.A.B., s. 19-20.

28 D. Jędrzejczyk: Teologia miasta, W: D. Jędrzejczyk (red.): Humanistyczne oblicze miasta. Warszawa 2004, Wydział Geografii i Studiów Regionalnych, s. 74.

29 Por. M. Golka: Imiona wielokulturowości, Warszawa 2010, „Muza”, s. 65; B. Hud: Wielokulturowośc Rzeczpospolitej: ukraiński punkt widzenia. W: Z. Mach, I. Głuszyńska (red.): Aktualne zagrożenia dla wartości związanych z wielokulturowością. Bielsko-Biała 2009, WSA, s. 107-114. 
miała charakter pragmatyczny i odnosiła się do ściśle określonych działań. Np. na poziomie zarządzania miastem odzwierciedlał się aktualny rozkład interesów ekonomicznych i politycznych poszczególnych grup mieszkańców ${ }^{30}$. Poszczególne grupy religijne prowadziły zaś własną działalność publiczną, np. charytatywną czy edukacyjną, skierowaną tylko do swojej grupy. Wiek XX na skutek wojen, migracji i przesiedleń ludności przyniósł wielkie zmiany w religijnym pejzażu miast. W przestrzeni miejskiej odnaleźć można zatem ślady skomplikowanej koegzystencji grup religijnych w postaci świątyń różnych wyznań, obok śladów zapomnienia i wymazywania przestrzeni, takich jak np. opuszczone cmentarze.

Dziedzictwo religijne miasta może zatem być odczytywane jako palimpsest - przestrzeń tworzona, wymazywana, rekonstruowana. „Oto gdzieś wyrasta cerkiew z kopułą, pewnego dnia z szyldów znika cyrylica i ukazuje się alfabet łaciński, oto katolicy przejmują kościół zbudowany przed wielu laty wysiłkiem społeczności protestanckiej, oto na miejscu żydowskiego cmentarza postawiono bloki mieszkalne i wytyczono ulice, oto z cokołu na rynku zrzucono figurę i znów zmieniono nazwy ulic... [...] W mieście palimpseście nowe nałożone jest na stare, dzisiejszy kurz opada na kurz wczorajszy. Każdy wiek, a nawet rok czy miesiąc, pozostawiły po sobie jakąś pamiątkę [...] Miasto - palimpsest to przestrzeń gubienia i znajdywania, pamięci i zapomnienia, niszczenia i budowania, spotkania i rozstania, narodzin i śmierci"31.

Współcześnie centralne położenie miejsc sakralnych w małym mieście, ich historia i wartość zabytkowa sprawiają, że kwestia religijnej identyfikacji może być pojmowana w nowych kategoriach, tj. kulturowego zasobu i elementu wizerunku jednostki osadniczej. Różnorodne ślady religijnej tożsamości przewijają się przez przewodniki, widokówki, opowieści, a kwestie religijnej różnorodności stają się także podstawą do różnorodnych działań władz w zakresie polityki kulturalnej miast - od konferencji po cykliczne festiwale. Zapomnianymi niegdyś miejscami kultów religijnych także w małych ośrodkach miejskich interesuje się wielu - od poszukujących korzeni i duchowości mieszkańców, przez lokalne stowarzyszenia czy pasjonatów regonu realizujących swoje

30 E. Moddelmog-Anweiler: Legacy of religious identities in the urban space of Bielsko-Biała. „Prace Geograficzne” Instytutu Geografii i Gospodarki Przestrzennej Uniwersytetu Jagiellońskiego 2014, Zeszyt 137, s. 137-158.

31 G. E. Karpińska: Miasto wymazywane. Historia Łódzkiego przypadku. W: I. Bukowska-Floreńska (red.): Miasto - przestrzeń kontaktu kulturowego i społecznego, „Studia Etnograficzne i Antropologiczne”, T. 8, Katowice 2004, UŚ, s. 165. 
zainteresowania, po lokalne władze koncentrujące się na zagospodarowaniu materialnych i niematerialnych zasobów kulturowych dla rozwoju społeczności lokalnej. Lokalne tradycje, cykliczne wydarzenia czy święta, także te o charakterze religijnym, stanowią $\mathrm{w}$ tej perspektywie tworzywo wizerunku, oferty turystycznej, ale i przestrzeń realizacji lokalnej polityki kulturalnej. Działania te przybierają zarówno formy oficjalnych strategii promocyjnych miasta, np. starania o wpis na listę dziedzictwa UNESCO, jak i działań grup i instytucji religijnych, np. modernizacja za pomocą środków europejskich. Wiele z nich, tj. imprezy plenerowe, festiwale i festyny, jest wynikiem aktywności lokalnej społeczności poprzez organizacje tzw. trzeciego sektora oraz hobbystów. Nie brakuje także dyskusji wokół pamięci oraz przykładów niezrozumienia takiej działalności, oporu wobec "fałszowania historii”. Należy tutaj zaznaczyć, iż konstruktywna krytyka jest w tym obszarze użyteczna i potrzebna. Coraz częściej pojawiają się jednak także pytania o edukacyjny i obywatelski wymiar troski o dziedzictwo na terenie miejsca zamieszkania ${ }^{32}$.

Historia i dziedzictwo są wciąż na nowo interpretowane przez aktualne odczytanie miasta, potrzeby i poszukiwania mieszkańców. Obszar ten pozostawia wciąż wiele pytań dotyczących form zagospodarowania religijnego dziedzictwa, kształtowania współczesnej narracji pamięci i różnorodności czy praktycznych pytań o to, do kogo należy religijne dziedzictwo i kto powinien być za nie odpowiedzialny - religijne wspólnoty, władze miasta, zainteresowani hobbyści? Wydaje się, iż odpowiedzi na te pytania w istotny sposób kształtują obecność tożsamości religijnej w lokalnej sferze publicznej.

\section{Podsumowanie}

„Miasto jest przestrzenią, w której realizowane są różne cele ludzkiej egzystencji. O miejscu i roli człowieka w przestrzeni miasta decydują nie tylko jego postawy indywidualne i kolektywne, lecz także wartości, które z kolei są kreowane przez określone systemy kulturowo-społeczne, polityczne czy religijne”33.

Powszechnie przyjmuje się, iż religia i praktyki religijne silnie oddziałują na środowisko wsi i małych miast, budując cechy charakterystyczne dla tych

32 K. Sztop-Rutkowska: Rola pamięci lokalnej w kształtowaniu demokratycznej tożsamości politycznej. W: R. Kusek, J. Sanetra-Szeliga (red.): Spoglądając na stereotyp. Kraków 2014, MCK, s. 58-77.

33 D. Jędrzejczyk (red.): Humanistyczne oblicze miasta. Warszawa 2004, Wydział Geografii i Studiów Regionalnych, s. 8. 
zbiorowości, tj. silną kontrolę społeczną czy tradycjonalizm. Rzeczywiście tożsamość religijna na poziomie lokalnym, prezentowana jedynie na podstawie różnorodnych wskaźników statystycznych, takich jak uczęszczanie do kościoła, praktykowanie tradycyjnych świąt czy sprzeciw wobec zmian kulturowych potwierdza taką wizję. W lokalnej przestrzeni publicznej coraz silniej uwidaczniają się jednak przemiany gospodarcze, kulturowe oraz przemiany komunikacji społecznej, wzorów konsumpcji i mediów, które modyfikują także znaczenia tożsamości religijnej na tle całokształtu życia publicznego w małych miastach. W powyższych refleksjach zaznaczyłam jedynie wybrane konteksty obecności religii w sferze publicznej na poziomie lokalnym. Wydaje się, że identyfikacja religijna może być współcześnie odmiennie konceptualizowana przez różnych uczestników lokalnego życia publicznego. Stanowi ona zarówno element identyfikacji mieszkańców, kulturowy komponent tożsamości lokalnej, jak i może stawać się swoistą bazą konstruowanej tożsamości ośrodka miejskiego. Konteksty obecności religijnych afiliacji w życiu publicznym są zatem bardzo zróżnicowane i obejmują praktyki życia codziennego mieszkańców, funkcjonowanie instytucji publicznych, przedsięwzięcia lokalnych władz czy narracje dotyczące pamięci i historii miejsca zamieszkującej je społeczności. W każdym z tych obszarów uwidacznia się także specyfika tożsamości religijnej w społeczeństwach Europy Środkowo-Wschodniej na tle przemian transformacji. Kwestie te otwierają pole badań dotyczących praktyki funkcjonowania instytucji religijnych w życiu publicznym, konstruowania narracji lokalnych tożsamości oraz legitymizacji tych znaczeń religijnej tożsamości przez mieszkańców.

\section{Bibliografia}

Ammerman N.: Everyday Religion. Observing Modern Religious Lives. Oxford - New York 2007, Oxford University Press.

Babiński G.: Religia a konflikty etniczne. Kategorie pojęciowe. Analizy wzajemnych relacji. Kraków 1994, „Nomos”.

Brace C., Bailey A. R., Harvey D. C.: Religion, Place and Space: A Framework for Investigating Historical Geographies of Religious Identities and Communieties. „Progress in Human Geography” 2006, No. 30.

http://phg.sagepub.com/content/30/1/28 (10.10.2014).

Borowik I., Doktór T.: Pluralizm religijny i moralny w Polsce. Raport $z$ badań.

Kraków 2001, „Nomos”. 
Borowik I.: Religijne oblicze Polski na tle Europy. W: A. Wójtowicz (red.): Kultury religijne. Perspektywy socjologiczne. Tyczyn 2005, WSSG.

Borowik I.: Religious Landscape on Central and Eastern Europe after Communism. W: J. A. Beckford, N. J. Demerath III (eds): The Sage Handbook of the Sociology of Religion. London 2007, Sage Publications.

Casanova J.: Religie publiczne w nowoczesnym świecie. Kraków 2004, „Nomos".

Castells M.: Siła tożsamości. Warszawa 2008, PWN.

Ciupak E.: Katolicyzm ludowy w Polsce: studia socjologiczne. Warszawa 1973, „Wiedza Powszechna”.

Demerath N. J.: The Rise of "Cultural Religion" in European Christianity: Learning from Poland, Northern Ireland and Sweden. "Social Compass” 2000, No. 47.

Elliot A.: Koncepcje „Ja”. Warszawa 2008, Wydawnictwo Sic!

Gajos L.: Wartości religijne a tożsamość mieszkańców wsi Podkarpacie w drodze do Unii Europejskiej. W: I. Borowik, K. Leszczyńska (red.): Wokót tożsamości. Teorie, wymiary, ekspresje. Kraków 2008, „Nomos”.

Geertz C.: Religia jako system kulturowy. W: W. Piwowarski (red.): Socjologia religii. Antologia tekstów. Kraków 2004, „Nomos”.

Golka M.: Imiona wielokulturowości. Warszawa 2010, „Muza”.

Halamska M.: Więź społeczna we współczesnym społeczeństwie polskim. Rekonstrukcja wedtug typologii Pawta Rybickiego. W: K. Frysztacki, A. Karwińska, M. Smagacz-Poziemska (red.): Obszary społecznego świata. Wokót socjologii Pawta Rybickiego. Kraków 2010, UJ.

Hud B.: Wielokulturowość Rzeczpospolitej: ukrainski punkt widzenia. W: Z. Mach, I. Głuszyńska (red.): Aktualne zagrożenia dla wartości związanych $z$ wielokulturowościa. Bielsko-Biała 2009, WSA.

Jedlicki J.: Jakiej cywilizacji Polacy potrzebuja. Studia z dziejów idei i wyobraźni XIX wieku. Warszawa 2002, WAB.

Jędrzejczyk D.: Teologia miasta. W: D. Jędrzejczyk (red.): Humanistyczne oblicze miasta. Warszawa 2004, Wydział Geografii i Studiów Regionalnych.

Kojder A. (red.): Encyklopedia socjologii. Warszawa 2002, Oficyna Naukowa. Karpińska G. E.: Miasto wymazywane. Historia Łódzkiego przypadku. W: I. Bukowska-Floreńska (red.): Miasto - przestrzeń kontaktu kulturowego i społecznego. „Studia Etnograficzne i Antropologiczne”, T. 8, Katowice 2004, UŚ.

Kopczyńska-Jaworska B.: Różnorodność obyczajów miejskich. W: Wielkie miasto. Czynniki integrujące i dezintegrujace. Łódź 1995, UŁ. 
Mach Z.: Symbols, Conflict and Identity. Essays in Political Anthropology. Albany, NY 1993, Suny Press.

Mariański J.: Religia w społeczeństwie ponowoczesnym. Studium socjologiczne. Warszawa 2010, Oficyna Naukowa.

Misztal W.: Maria Ossowska: miasto i moralność. W: W. Misztal, J. Styka (red.): Stare i nowe struktury społeczne w Polsce. Czynniki miastotwórcze w okresach wielkich zmian społecznych. T. III. Lublin 2002, UMCS.

Mielicka H.: Odpusty w matym miasteczku, W: M. Meducka, R. Renz (red.): Miasteczka polskie w XIX i XX wieku jako zjawisko kulturowo-obyczajowe, Kielce 1998, WSP.

Mielicka H.: Tożsamość indywidualna a tożsamość spoteczna jako wymiar religijności. W: M. Libiszowska-Żółtkowska (red.): Tożsamości religijne w społeczeństwie polskim. Socjologiczne studium przypadków. Warszawa, 2009, Difin.

Moddelmog-Anweiler E.: Legacy of religious identities in the urban space of Bielsko-Biała. „Prace Geograficzne” Instytutu Geografii i Gospodarki Przestrzennej Uniwersytetu Jagiellońskiego 2014, Zeszyt 137.

Odoj G.: Tożsamość kulturowa społeczności małomiasteczkowej. Katowice 2007, UŚ.

Olszewski D.: Życie religijne matego miasta $w$ XIX i poczatkach XX wieku. Zarys problematyki badawczej. W: R. Kołodziejczyk (red.): Miasteczka polskie w XIX i XX wieku. Z dziejów formowania się społeczności. Kielce 1992, Kieleckie Towarzystwo Naukowe.

Pollack D., Muller O.: Religiousness in Central and Eastern Europe: Towards Individualisation? W: I. Borowik (red.): Religions, Churches and Religiosity in post-Comunist Europe. Kraków 2006, „Nomos”.

Robertson R.: Mapping the Global Condition: Globalization as the Central Concept. "Theory, Culture and Society" 1990, No. 7 (2-3).

Sommers M.R.: Citizenship and the place of the public sphere: Law, community, and the political culture in the transition to democracy. "American Sociological Review" 1993, No. 58 (5).

Szacki J.: Historia myśli socjologicznej. Warszawa 2004, PWN.

Sztompka P.: Socjologia. Analiza społeczeństwa. Kraków 2012, „Znak”.

Szwed R.: Tożsamość religijna W: M. Libiszowska-Żółtkowska, J. Mariański (red.): Leksykon socjologii religii. Zjawiska - badania - teorie. Warszawa 2004, Verbinum.

Sztop-Rutkowska K.: Rola pamięci lokalnej w kształtowaniu demokratycznej 
tożsamości politycznej. W: R. Kusek, J. Sanetra-Szeliga (red.): Spoglądając na stereotyp. Kraków 2014, MCK.

Świątkiewicz W.: Relikt przeszłości czy żywa codzienność? Refleksje wokót badań socjologicznych nad religijnościq wspótczesna w krajach wyszehradzkich. W: J. Budniak, A. Kasperek (red.): Polska - Czechy-Stowacja. Oblicza religijności. Katowice 2011, PAU - Oddział Katowice.

Wnuk-Lipiński E.: Socjologia życia publicznego. Warszawa 2006, „Scholar”. Woroniecka G.: Interakcja symboliczna a hermeneutyczna kategoria przed-rozumienia. Warszawa 2003, Oficyna Naukowa.

\section{Identity - religion - town. Contexts of the presence of religious identity in the local space of public life in East-Central Europe}

\section{Summary}

Religious identity in the societies of Central and Eastern Europe is currently undergoing strong changes associated with the consequences of systemic transition, cultural changes and alterations within the churches. In the new democratic conditions in countries such as Poland, Slovakia and Ukraine, religious identity becomes one of the collective identities manifested in the public sphere and important not only in terms of public discourse but also of local contexts, i.e. local identity and identity of the place. In the article, the author presents some reflections on the meanings of collective religious identity in the local public space. These are insights that emerge from qualitative research. The article outlines three important contexts of meaning of religious identity in the local space of public life: 1) specificity of the role of religion and religiosity in public life in this part of Europe, 2) cultural and institutional significance of religious identification in relation to local identity, 3 ) issues of the narrative concerning the multireligious sacred heritage in local communities, which introduces a new way of perception of religious identity as a cultural resource associated with the place and memory.

Key words: religious identity, Central Europe, public sphere, local community, heritage 